\title{
A Five-Year Retrospective Analysis of Basal Cell Carcinoma: A Monocentric Study
}

\author{
Bazal Hücreli Karsinomun Beş Yıllık Retrospektif Analizi: \\ Tek Merkezli Çalışma
}

\section{Seyma OZKANLI ${ }^{\oplus}$, Tuce SOYLMEZ $^{\circledR}$, Havva KESKIN $^{\circledR}$, Hatice SENELDIR ${ }^{\circledR}$, Fatıma Müberra SAHIN ${ }^{\bullet}$, Aysenur ÇETINKAYA $\odot$, Andac GOKTURK $\odot$, Nagihan AYCICEK $\odot$, Kubra DUZ $\odot$, Bengu COBANOGLU SIMSEK $\odot$}

Ethics Committee Approval: This study was approved by the Istanbul Medeniyet University Goztepe Training and Research Hospital, Clinical Studies Ethics Committee, 22 May 2019, 2019/0264. Conflict of interest: The authors declare that they have no conflict of interest.

Funding: None.
Cite as: Ozkanli S, Soylemez T, Keskin H, et al. A Five-Year Retrospective Analysis of Basal Cell Carcinoma: A Monocentric Study. Medeni Med J. 2020;35:219-25.

\begin{abstract}
Objective: Our aim in this study is to define the histopathological subtypes, body site distribution, and incidence rates of single or multiple of BCCs. The study is conducted on patients from a single institution in Istanbul which has a migrant-receiving population reflecting that of the country overall.

Method: We retrospectively analyzed data concerning 896 cases of BCC seen between 2014 and 2018. Data about patient demographics (age and sex), tumor diameter,its anatomic localization, histological type, presence of ulceration, lymphovascular/perineural invasion, and single or multiple tumor formations were retrieved from both the hospital's automated system and archived records of the pathology clinic.

Results: Our univariate analysis showed that the patients' age, tumor size, and tumor multicentricity were all significantly related to their gender $(p=0.011, p=0.001$, and $p=0.021$, respectively). Further, age, male gender, and tumor size were all significantly related to tumor multicentricity $(p=0.003, p=0.021$, and $p=0.001$, respectively). BCC was most commonly found in male, and the diameters of the BCC tumors were also larger in male patients. Multiple BCC was more frequently seen in older and male patients, and the tumors had larger diameters in these groups. The nodular type of BCC was the most frequently seen type in all age groups.

Conclusion: As our study is the first BCC study that has the greatest number of cases in Turkey and as Istanbul reflects the population of Turkey, it is important for the data of BCC cases in Turkey.
\end{abstract}

Keywords: Basal cell carcinoma, Turkish, tumor multicentricity, retrospective study, patient characteristics

öz

Amaç: Bu çalışmada amacımız göc almasından dolayı bütün ülke genelini yansıtan karıșı insan populasyonuna sahip Istanbul'da Bazal Hücreli Karsinom (BHK) vakalarının histopatolojik alt tiplerinin, vücutta dağılım bölgelerinin, tek ve multiple görülme oranlarının belirlenmesidir.

Yöntem: 2014-2018 yılları arasında 896 BHK vakası ile ilgili verileri retrospektif olarak analiz ettik. Hastaların yaşı, cinsiyeti, tümör çapı, tümör lokalizasyonu, histolojik tip, ülserasyon, lenfovasküler/perinöral invazyon ve multiple tümör varlığı hastanenin ve patoloji kliniğinin arşiv kayitlarından elde edildi.

Bulgular: Tek değişkenli analizde yaş, tümör boyutu ve multiple tümör varlığı cinsiyet ile anlamlı olarak ilișkili bulunmustur (sırasıyla $p=0,011, p=0,001$ ve $p=0,021$ ). Ayrıca, yaș, erkek cinsiyet ve tümör boyutu multiple tümör varlığıyla anlamlı olarak ilișkiliydi (sırasıyla $p=0,003, p=0,021$ ve $p=0,001$ ). BHK erkeklerde daha yaygın ve BHK çaplarının da erkek hastalarda daha büyük olduğu gözlendi. Multiple tümörler, yaşlı ve erkek hastalarda daha sık görüldü. Bu tümörler yine bu gruplarda daha büyük çaplara sahipti. Nodüler BHK tipi tüm yaş gruplarında en sık görülen tip olarak bulundu.

Sonuç: Çalışmamız, Türkiye'de en fazla vakaya sahip olan ilk BHK çalışması olması ve istanbul, Türkiye’nin nüfusunu yansıtıyor olmasından dolayı, Türkiye'deki BHK vakalarının verileri için önemlidir.

Anahtar kelimeler: Bazal hücreli karsinom, Türk, multiple tümör, Retrospektif çalışma, hasta özellikleri
Received: 29 May 2020

Accepted: 29 August 2020

Online First: 30 September 2020

Corresponding Author: S. Ozkanli

ORCID: 0000-0002-3357-1059

Istanbul Medeniyet University, Faculty of Medicine,

Department of Pathology, Istanbul, Turkey

seymaozkanli@gmail.com

T. Soylemez
ORCID: 0000-0003-3030-7030

H. Seneldir

ORCID: 0000-0002-1429-6776

B. Cobanoglu Simsek

ORCID: 0000-0003-2639-2017

Istanbul Medeniyet University, Faculty of Medicine, Department of

Pathology, Istanbul, Turkey

H. Keskin

ORCID: 0000-0003-1794-4473

Istanbul Medeniyet University, Faculty of Medicine, Department of Internal Medicine, Istanbul, Turkey

F.M. Şahin

ORCID: 0000-0001-9203-4379

A. Çetinkaya

ORCID: 0000-0003-4168-2856

A. Göktürk

ORCID: 0000-0003-0383-7685

N. Ayçiçek

ORCID: 0000-0002-9217-8716

K. Duz

ORCID: 0000-0001-8067-7043

Istanbul Medeniyet University, Faculty of Medicine, Istanbul, Turkey

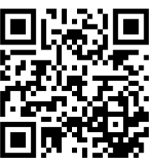




\section{INTRODUCTION}

Basal cell carcinoma (BCC) is the most common type of cancer worldwide, and its occurrence is inversely related to a country's geographical latitude ${ }^{1}$. BCC is most frequently seen in lightskinned people, generally as a solitary lesion, although it can also develop as multiple lesions ${ }^{2}$. The risk of different tumor formations is high in patients with two or more BCCs ${ }^{1}$. Many studies have shown that the risk of having multiple BCCs is increased in cases in whom the BCC was initially localized on the trunk ${ }^{3}$. Yet the individual risk factors change, based on age, gender, race, and genetics. Additionally, the patient's birthplace, incidence of radiotherapy in childhood, and skin type are the main risk factors for the development of multiple BCCs ${ }^{4}$.

BCC is a carcinoma originating from basal cells of the interfollicular epidermis and/or hair follicles. It exhibits morphological variability, but it invariably contains islands or a nest of peripherally palisaded basaloid cells with hyperchromatic nuclei and scant cytoplasm ${ }^{1}$. Various BCC subtypes are classified in 2018 by the World Health Organization (WHO) according to their different growth patterns. According to this classification, the histological subtypes of BCCs are evaluated under two groups, based on their risk of recurrence. The higher-risk group includes basosquamous carcinoma, sclerosing/morphoeic BCC, infiltrating BCC, BCC with sarcomatoid differentiation, and micronodular BCC subtypes, while the lower-risk group includes nodular BCC, superficial BCC, pigmented BCC, infundibulocystic BCC, and fibroepithelial $\mathrm{BCC}^{1}$.

The aim of this study is to define the histopathological subtypes, body site distribution, and incidence rate(s) of single or multiple BCCs. The study is conducted in a single institution in Istanbul which has a migrant-receiving population reflecting that of the country overall.

\section{MATERIAL and METHODS}

A total of 896 BCC cases were investigated by the pathology clinic between 2014 and 2018, that were identified by scanning our hospital's automated system. Patients with xeroderma pigmentosum or nevoid BCC syndrome were not included in this study. Relevant clinical and pathological data were also gathered from the same automated system. Data concerning patient demographics (age and sex), tumor diameter, its anatomic localization, histological type, presence of ulceration, lymphovascular/perineural invasion, and single or multiple tumor formations were retrieved from both the hospital's automated system and the archived records of the pathology clinic. We divided the cases according to the WHO Classification in 2018 based on the histopathological subtypes. We evaluated the tumors characterized by large tumor nodules in the dermis as a nodular BCC (Figure 1A). Keratotic BCC, with tumor nests showing central mature keratinization; nodulocystic BCC, cystic degeneration within tumor islands; and adenoid BCC, with cribriform

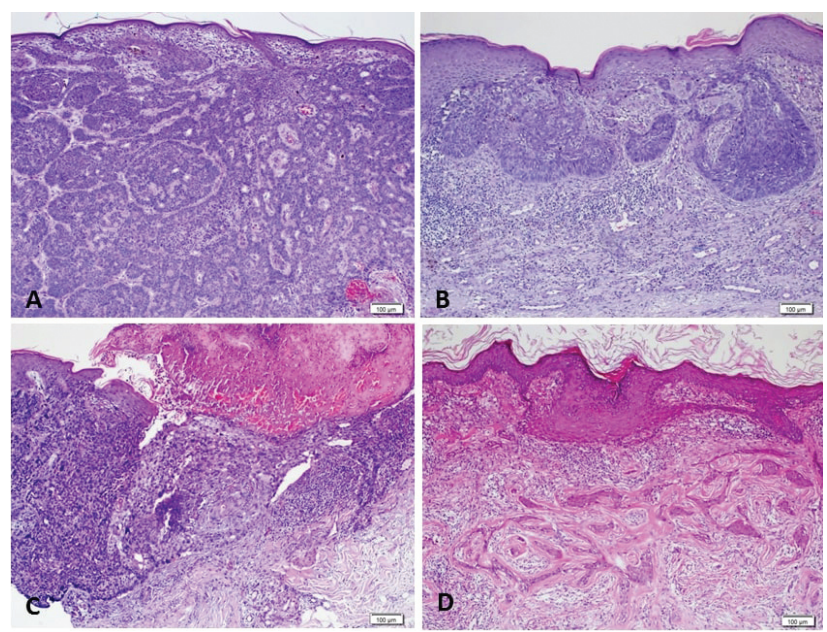

Figure 1. A-Nodular basal cell carcinoma. The tumour forms solid tumour nodules. Islands of basaloid cells within peripheral palisading extend into the dermis (H\&Ex 100). B-Superficial basal cell carcinoma. Multifocal nests of atypical basaloid epithelium arising as buds from the basal layer of the epidermis. These nests remain confined to the papillary dermis (H\&Ex 100). C-Basosquamous carcinoma. Infiltrative basaloid strands intermixed with atypical squamous cells (H\&Ex 100). D-Morphoeic/Sclerosing basal cell carcinoma. Narrow cords of tumour cells are surrounded by abundant collagen (H\&Ex 100). 
nests, were evaluated as variants of nodular $\mathrm{BCC}^{1}$. A superficial BCC is composed of multiple small islands of basaloid cells attached to the undersurface of the epidermis and usually confined to the papillary dermis ${ }^{5}$ (Figure 1B). When differentiation of neoplastic squamous foci occurs, the tumors are labeled as of basosquamous type ${ }^{6}$ (Figure 1C). A morpheaform BCC is composed of thin strands and nests of basaloid cells showing only limited peripheral palisading. The surrounding stroma is dense and sclerotic ${ }^{6}$ (Figure 1D). A pigmented BCC contains melanin pigment ${ }^{1}$. A fibroepithelial $\mathrm{BCC}$ is composed of delicate, interanastomosing strands of basaloid cells surrounded by abundant fibroblastic stroma ${ }^{1}$. An infiltrating BCC is characterized by small, irregular clumps of basaloid cells with a jagged border, and limited peripheral palisading ${ }^{6}$. The ones which contain more than one histopathological subtype are regarded as mixed type.

\section{Statistical analysis}

The variables of interest in the present study were expressed as either the percentage or mean \pm the standard deviation, depending on which approach was the most appropriate to describe the data in question. One-way analysis of variance (ANOVA) or chi-square tests were used to compare the data. IBM SPSS (version 25.0 for Windows) was used to conduct all analyses, and $\mathrm{p}<0.05$ was considered to be statistically significant.

\section{RESULTS}

\section{Patients}

Descriptive statistics concerning all patients are presented in Table 1. A total of 896 patients were included in this study. More specifically, 477 male (53.2\%) and 419 female patients $(46.8 \%)$ with a mean age of 68.1 years (range: 20-113 years)

Table 1. The distribution of descriptive characteristics of all cases $(n=896)$ and gender subgroups.

\begin{tabular}{|c|c|c|c|c|}
\hline & \multirow[t]{2}{*}{ All cases } & \multicolumn{2}{|c|}{ Gender } & \multirow[b]{2}{*}{$\mathbf{p}$} \\
\hline & & Female & Male & \\
\hline & \multicolumn{3}{|c|}{ Mean \pm SD or $n(\%)$} & \\
\hline Gender & 896 & $419(46.8)$ & $477(53.2)$ & \\
\hline Age (years) & $68.1 \pm 13.3$ & $66.97 \pm 14.1$ & $69.2 \pm 12.5$ & $0.011^{*}$ \\
\hline$\cdot<40$ & $31(3.5)$ & $16(3.8)$ & $15(3.1)$ & \\
\hline$\cdot 40-60$ & $201(22.4)$ & $114(27.2)$ & $87(18.2)$ & \\
\hline$\cdot 61-80$ & $505(56.4)$ & $221(52.7)$ & $284(59.5)$ & \\
\hline$\cdot>80$ & $159(17.7)$ & $68(16.2)$ & $91(19.1)$ & \\
\hline Tumor size (mm) & $8.7 \pm 6.6$ & $7.9 \pm 6.4$ & $9.4 \pm 6.6$ & $0.001^{*}$ \\
\hline$\cdot 1-10$ & $690(77.7)$ & 343 (82.9) & $347(73.2)$ & \\
\hline$\cdot 11-20 \mathrm{~mm}$ & $164(18.5)$ & $53(12.8)$ & $111(23.4)$ & \\
\hline$\cdot \geq 21 \mathrm{~mm}$ & $34(3.8)$ & $18(4.3)$ & $16(3.4)$ & \\
\hline \multicolumn{5}{|l|}{ Tumor localization } \\
\hline - Scalp & 95 (10.6) & $42(10.0)$ & $53(11.1)$ & $0.106^{*}$ \\
\hline - Face & $636(71)$ & $312(74.5)$ & $324(67.9)$ & \\
\hline - Neck & $18(2.0)$ & $7(1.7)$ & $11(2.3)$ & \\
\hline - Trunk & $92(10.2)$ & $34(8.1)$ & $58(12.2)$ & \\
\hline - Extremities & $43(4.8)$ & $16(3.8)$ & $27(5.7)$ & \\
\hline - Not mentioned & $12(1.3)$ & 8 (1.9) & $4(0.8)$ & \\
\hline \multicolumn{4}{|l|}{ Histological subtype } & $0.454^{*}$ \\
\hline - Nodular & $749(83.6)$ & $352(84.0)$ & $397(83.2)$ & \\
\hline - Superficial & $86(9.6)$ & $35(8.4)$ & $51(10.7)$ & \\
\hline - Basosquamous & $23(2.6)$ & $14(3.3)$ & $9(1.9)$ & \\
\hline - Morpheaform & $23(2.6)$ & $12(2.9)$ & $11(2.3)$ & \\
\hline - Other subtypes & $15(1.7)$ & $6(1.4)$ & $9(1.9)$ & \\
\hline Ulceration (present) & $256(28.6)$ & $113(27.0)$ & $143(30.0)$ & $0.335^{* *}$ \\
\hline Tumor multicentricity (present) & $81(9.0)$ & $28(6.7)$ & $53(11.1)$ & 0.021 ** \\
\hline Lymphovascular invasion (present) & $5(0.6)$ & $3(0.7)$ & $2(0.4)$ & $0.669^{* *}$ \\
\hline Perineural invasion (present) & $12(1.3)$ & $5(1.2)$ & $7(1.5)$ & $0.955^{* *}$ \\
\hline
\end{tabular}

*One way ANOVA test, * ${ }^{*}$ Chi-square test 
were included in this study. The mean tumor size was $8.7 \mathrm{~mm}$ (median: $7 \mathrm{~mm}$; range: 0.8-65 $\mathrm{mm})$. The tumor was evaluated as for its localization in six categories: scalp $(10.6 \% ; n=95)$, face (71\%; $n=636)$, neck (2\%; $n=18)$, trunk $(10.3 \%$; $\mathrm{n}=92$ ), extremities $(4.8 \% ; \mathrm{n}=43)$, and unknown localization $(1.3 \% ; n=12)$. The facial site distribution of the BCCs among patients was as follows: the nasal (31.7\%) and periorbital (10.5\%) regions were the most common sites for facial BCC, followed by ear $(8.8 \%)$, cheeks $(7.5 \%)$, forehead (7.4\%), perioral region (2.9\%), and jaw (1.2\%). Histopathological subtypes of our cases with BCC were as follows: nodular ( $n=749 ; 83.6 \%)$, superficial ( $n=86: 9.6 \%)$, basosquamous ( $n=23 ; 2.6 \%)$, morpheaform ( $\mathrm{n}=23 ; 2.6 \%)$, and other subtypes: mixed, pigmented, fibroepithelial, micronodular, and infiltrative) ( $n=15 ; 1.7 \%)$. Eighty-one patients (9\%) had multiple BCCs. Ulceration was present in
256 (28.6\%), lymphovascular invasion (LVI) in five $(0.6 \%)$, and perineural invasion in 12 cases $(1.3 \%)$.

\section{Relationship between the clinicopathologic parameters and gender}

We compared the clinicopathologic features of the female patients with those of the male patients. The mean ages of the female, and male patients were 66.9 , and 69.2 years, respectively. Our univariate analysis (Table 1) showed that the patients' age, tumor size, and tumor multicentricity were all significantly related to their gender $(p=0.011$, $p=0.001$, and $p=0.021$, respectively). We observed that the male patients were older than the female patients. When compared to the patients in the 40-to 60-year-old age group, greater number of patients in the 61-to 80-year-old group and the $\geq 81$-year-old group were male. The mean tumor size of the female patients was $7.9 \mathrm{~mm}$, while that

Table 2. Relationship between clinicopathological parameters and tumor multicentricity.

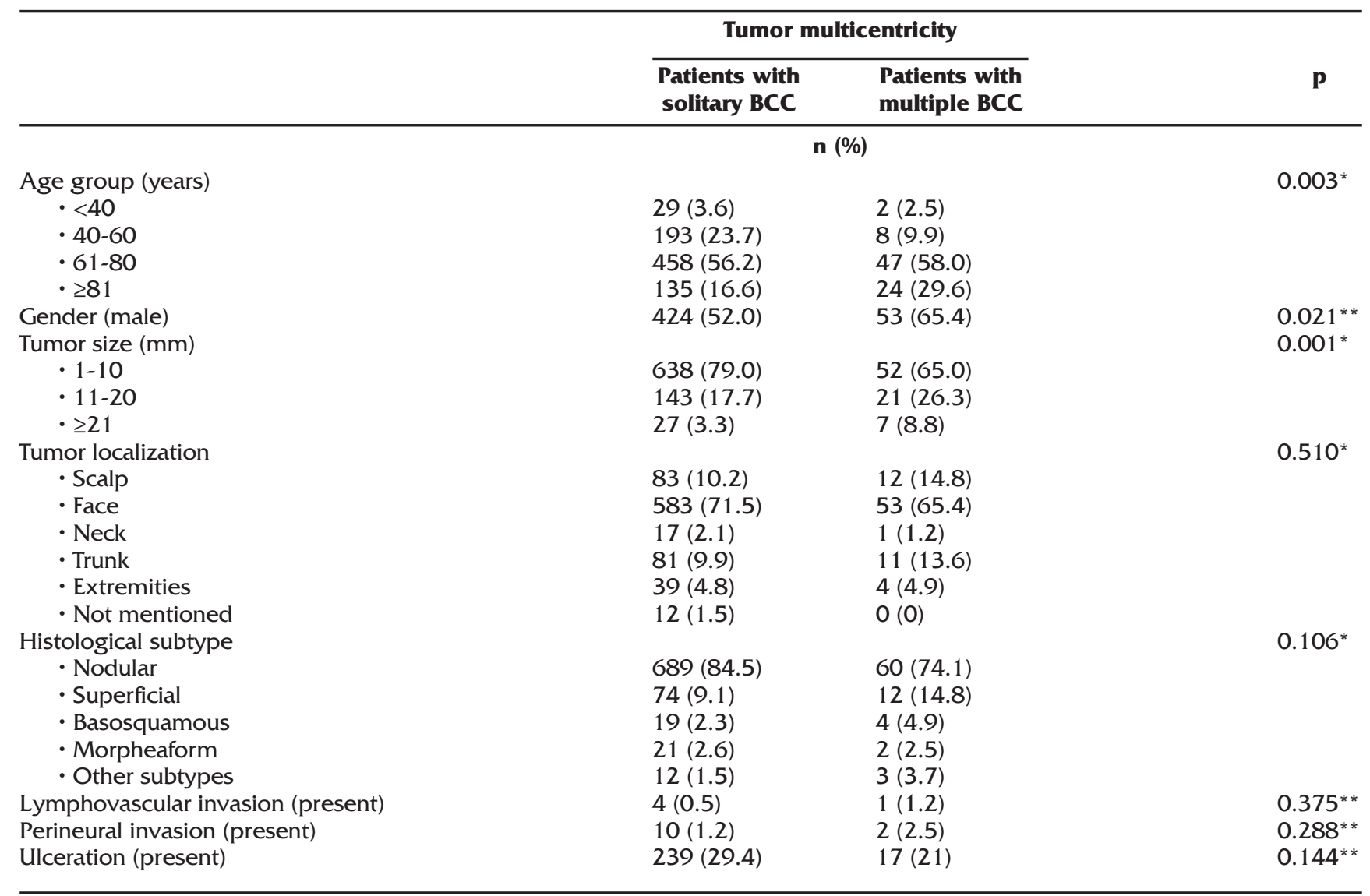

*One way ANOVA test, * ${ }^{*}$ Chi-square test 
Table 3. Tumor histopathology and localization for each age groups.

\begin{tabular}{|c|c|c|c|c|c|}
\hline & \multicolumn{4}{|c|}{ Age (years) } & \multirow[b]{2}{*}{$\mathbf{p}$} \\
\hline & $<40(n, \%)$ & 40-60 (n, \%) & $61-80(n, \%)$ & $\geq 81(n, \%)$ & \\
\hline Histological subtype & 31 & 201 & 505 & 159 & 0.003 \\
\hline - Nodular & $25(80.6)$ & $166(82.6)$ & $424(84.0)$ & $134(84.3)$ & \\
\hline - Superficial & $5(16.1)$ & $27(13.4)$ & $44(8.7)$ & $10(6.3)$ & \\
\hline - Basosquamous & $0(0.0)$ & $1(0.5)$ & $15(3.0)$ & $7(4.4)$ & \\
\hline • Morpheaform & $1(3.2)$ & $6(3)$ & $12(2.3)$ & $4(2.5)$ & \\
\hline - Other subtypes & $0(0.0)$ & $1(0.5)$ & $10(2.0)$ & $4(2.5)$ & \\
\hline Tumor localization & 31 & 201 & 505 & 159 & 0.118 \\
\hline - Scalp & 4 (12.9) & $20(10.0)$ & $61(12.1)$ & $10(6.3)$ & \\
\hline - Face & $18(58.1)$ & $140(69.7)$ & $354(70.1)$ & $124(78.0)$ & \\
\hline - Neck & $2(6.5)$ & $3(1.5)$ & $10(2.0)$ & $3(1.9)$ & \\
\hline - Trunk & $6(19.3)$ & $27(13.4)$ & $45(8.9)$ & $14(8.8)$ & \\
\hline - Extremities & $1(3.2)$ & $6(3)$ & $29(5.7)$ & $7(4.4)$ & \\
\hline - Not mentioned & $0(0.0)$ & $5(2.5)$ & $6(1.2)$ & $1(0.6)$ & \\
\hline
\end{tabular}

value was $9.4 \mathrm{~mm}$ for the male patients. When compared to the patients who had a tumor size of 1-10 mm, greater number of patients with a tumor size of 11-20 mm were male. There was no significant correlation between patients' tumor localization, histological subtype, LVI, perineural invasion, or ulceration and their gender.

\section{Comparison of patients with solitary BCCs and those with multiple BCCs in terms of their clin- icopathologic parameters}

Age, male gender, and tumor size were all found to be significantly related to tumor multicentricity ( $p=0.003, p=0.021$, and $p=0.001$, respectively). The majority of patients were in the 61-to 80-yearold age group. Patients with multiple BCCs were older than the patients with a solitary BCC. When compared with patients with solitary BCCs cases with multiple BCCs were more numerous in the 11-20 $\mathrm{mm}$ and $\geq 21 \mathrm{~mm}$ tumor size groups. There was no significant correlation between tumor localization, histological subtype, LVI, perineural invasion, ulceration, and tumor multicentricity (Table 2).

\section{Relationship of histological subtype and tumor localization with age}

The patients' histological subtype was found to be significantly associated with their age $(p=0.003)$. The majority of patients in each age group had the nodular type of BCC (83.6\%). However, there was no significant correlation between tumor localization and age (Table 3).

\section{DISCUSSION}

Basal cell carcinoma is the most common malignancy in humans ${ }^{7}$. BCC constitutes $70 \%$ of all skin cancers $^{6}$. Ultraviolet radiation is the main risk factor for skin cancers, including BCC. Living in the equatorial zone, significant individual exposure to sunlight, and having fair skin are other important risk factors for BCC occurrence ${ }^{1}$. BCC has one of the highest prevalence rates of somatic mutations of all malignant tumors. Several key genes have been implicated in BCC pathogenesis, particularly proto-oncogenes and tumor suppressor genes. These include (amongst others) the $\mathrm{PTCH}^{1}$ and SMO genes (which are key components of the hedgehog pathway), the TP53 gene, and other RAS proto-oncogene family members ${ }^{1,8}$.

Different histological subtypes can develop in different anatomical locations. The nodular BCC is predominantly seen on the head and neck region, while the superficial type is more commonly seen on the trunk ${ }^{1}$. The occurrence rate is high, especially on the areas exposed to sunlight. It has been stated that $64 \%$ of BCC cases occur on the head region and $24 \%$ on the trunk ${ }^{1}$. In our study, 
$88.9 \%$ of nodular BCCs were located on the head and neck regions. However, $51.2 \%$ of superficial BCCs are located on the head and neck regions, followed by $34.8 \%$ on the trunk. When all the cases were analyzed, $82 \%$ of them were seen on the head and neck regions, and $10.3 \%$ of them on the trunk. The occurrence rates of histopathological subtypes of the tumor at different anatomical locations are similar in other studies?.

Istanbul comprises $18 \%$ of Turkey's population and receives migration from all cities in Turkey. Up to now, this study has studied the greatest number of BCC cases in Istanbul, reflecting the country's human diversity. Turkey is located in the Northern Hemisphere between Asia and Europe on the geographical coordinates of $36-42^{\circ}$ North latitudes, and $26-45^{\circ}$ East longitudes. Therefore, people in Turkey are exposed to sunlight more frequently than in many other countries in Europe. People living in Turkey are mostly Caucasians. Turkish population includes several ethnic groups. The hospital's automated system does not provide information about ethnicities; therefore, we did not take ethnicity into account. BCC is usually more commonly seen in males which could be explained by their higher occupational and recreational exposure to UV light ${ }^{1}$. Also, as opposed to males, females tend to cover their bodies due to religious and social customs in Turkey. In our study, male/ female ratio was 1.1 which is comparable to the gender distribution in previous studies conducted on Caucasians, like Roenigk's and Gallagher's studies ${ }^{10,11}$.

Van Lersel et al. ${ }^{12}$ and Ramachandran et al. ${ }^{13}$ reported that males older than 60 years old were at an increased risk of multiple BCCs. Adachi et al. ${ }^{2}$ compared clinicopathological data in a study of 327 cases with solitary and multiple tumors. No gender variation was found between the two groups, but there was a statistically significant difference in the incidence rate of multiple BCCs in our study, occurring more frequently in males and older patients.
The average age of patients with BCC in our study was approximately 68.1 years. Moore et al. ${ }^{14}$ stated that it occurs at older ages in Asians than Caucasians. While there are studies reporting that risk of multiple BCC increases at the age of 60 years and over, there are also some studies showing that age is not a risk factor for multiple $\mathrm{BCCs}^{4,12,13,15}$. A significant relationship between age and the number of tumors was shown in our study. The $87.6 \%$ of multiple BCC, and $72.8 \%$ of the solitary BCC cases were found in patients over the age of 60 years. Thus, our study demonstrates that age is a very important risk factor in the development of multiple BCCs.

Most commonly nodular, then the superficial and infiltrative types of BCC are seen ${ }^{1,16,17}$. In our study, our cases had nodular (83.6\%), superficial (9.6\%), basosquamous (2.6\%), and morpheaform (2.6\%) subtypes of BCC similar to the literature. In our study, the third most common types are morpheaform BCC and basosquamous carcinoma, as a finding different from the literature.

\section{CONCLUSION}

As our study has covered the highest number of cases in Istanbul, it conveys highly valuable data for BCC cases in Turkey. In our study, BCC was more frequent and in larger diameters in male patients. Multiple BCCs were more frequent in the elderly, and of larger size in males. The nodular type was the most often seen BCC in all age groups.

\section{REFERENCES}

1. Elder DE, Massi D, Scolyer RA, Willemze R, editors. WHO Classification of Skin Tumours. 4th ed. International Agency for Research on Cancer; 2018. p:26-34.

2. Adachi K, Yoshida Y, Noma H, Goto H, Yamamoto O. Characteristics of multiple basal cell carcinomas: The first study on Japanese patients. J Dermatol. 2018;45:118790. [CrossRef]

3. Kiiski V, de Vries E, Flohil SC, et al. Risk factors for single and multiple basal cell carcinomas. Arch Dermatol. 2010;146:848-55. [CrossRef]

4. Hallaji Z, Rahimi H, Mirshams-Shahshahani M. Com- 
parison of risk factors of single Basal cell carcinoma with multiple Basal cell carcinomas. Indian J Dermatol. 2011;56:398-402. [CrossRef]

5. Patterson JW. Weedon's Skin Pathology. $4^{\text {th }}$ ed. London: Elsevier; 2016.

6. Calonje E, Brenn T, Lazar AJ, Billings SD. McKee's Pathology of the Skin. $5^{\text {th }}$ ed. London: Elsevier; 2020.

7. Lomas A, Leonardi-Bee J, Bath-Hextall F. A systematic review of worldwide incidence of nonmelanoma skin cancer. Br J Dermatol. 2012;166:1069-80. [CrossRef]

8. Al-Qarqaz F, Marji M, Bodoor K, et al. Clinical and Demographic Features of Basal Cell Carcinoma in North Jordan. J Skin Cancer. 2018;2018:2624054. [CrossRef]

9. Pranteda G, Grimaldi M, Lombardi M, et al. Basal cell carcinoma: differences according to anatomic location and clinical-pathological subtypes. G Ital Dermatol Venereol. 2014;149:423-6.

10. Roenigk RK, Ratz JL, Bailin PL, Wheeland RG. Trends in the presentation and treatment of basal cell carcinomas. J Dermatol Surg Oncol. 1986;12:860-5. [CrossRef]

11. Gallagher RP, Ma B, McLean DI, et al. Trends in basal cell carcinoma, squamous cell carcinoma, and melanoma of the skin from 1973 through 1987. J Am Acad Dermatol. 1990;23:413-21. [CrossRef]
12. van lersel CA, van de Velden HV, Kusters CD, et al. Prognostic factors for a subsequent basal cell carcinoma: implications for follow-up. Br J Dermatol. 2005;153:107880. [CrossRef]

13. Ramachandran S, Fryer AA, Lovatt TJ, et al. Combined effects of gender, skin type and polymorphic genes on clinical phenotype: use of rate of increase in numbers of basal cell carcinomas as a model system. Cancer Lett. 2003;189:175-81. [CrossRef]

14. Moore MG, Bennett RG. Basal cell carcinoma in asians: a retrospective analysis of ten patients. J Skin Cancer. 2012;2012:741397. [CrossRef]

15. Levi F, Randimbison L, Maspoli M, Te VC, La Vecchia C. High incidence of second basal cell skin cancers. Int J Cancer. 2006; 119:1505-7. [CrossRef]

16. Cameron MC, Lee E, Hibler BP, et al. Basal cell carcinoma: Epidemiology; pathophysiology; clinical and histological subtypes; and disease associations. J Am Acad Dermatol. 2019;80:303-17. [CrossRef]

17. Rivers JK, Mistry BD, Hung T, Vostretsova K, Mistry N. A 13-Year Retrospective Study of Basal Cell Carcinoma in a Canadian Dermatology Practice: A Comparison Between Anatomical Location and Histopathologic Subtypes. J Cu$\tan$ Med Surg. 2016;20:233-40. [CrossRef] 